\title{
Chapter 9 \\ Branding Cosmopolitanism and Place Making in Saint Laurent Boulevard, Montreal
}

\author{
Marie-Laure Poulot
}

\subsection{Introduction}

As a social and subjective construction, cosmopolitanism can take many forms since there is no consensus around its definition: for some authors, "it is a sort of 'empty signifier' to be filled with specific and often rather different contents in differently situated cultural worlds" (Vanolo 2017, 8; see also Binnie et al. 2006; Söderström 2006). Even if expressions other than cosmopolitanism are used in Montreal such as multiculturalism, interculturalism (for Quebec, in contradistinction to the rest of $\mathrm{Canada}^{1}$ ) or cultural diversity, I have chosen to use the concept of cosmopolitanism exactly for its multiple significations. Following David Hollinger (1995), I prefer cosmopolitanism rather than multiculturalism, which tends to divide society into homogenous and closed cultural communities, where each individual should identify with one single group. Cosmopolitanism values individuality and a non-exclusive affiliation to a plurality of groups that are constantly evolving (Hollinger 1995). In Montreal, the empirical realities observed on the ground reflect the four main dimensions of cosmopolitanism. There is a diverse population linked to the rise of international migration in a globalized world. There is a political cosmopolitanism which questions "Montrealness" between openness to alterity and Quebec nationalism (Létourneau 2003) as well as a commodified cosmopolitanism or "consumerist cosmopolitanism" (Calhoun 2002) which is used as a tool to branding the city (Hemelryk et al. 2009; Kavaratzis and Ashworth 2005). Finally, there is everyday cosmopolitanism. A growing literature has framed

\footnotetext{
${ }^{1}$ Quebec province proclaims its specificity with its intercultural policy to distance itself from the wider Canadian policy of multiculturalism established to hush up claims for Quebec sovereignty and to merge French-Canadian identity into a Canadian one (Kymlicka 1998).
}

M.-L. Poulot $(\bowtie)$

University Paul Valery, Montpellier, France

(C) The Author(s) 2021

C. Lejeune et al. (eds.), Migration, Urbanity and Cosmopolitanism in a

Globalized World, IMISCOE Research Series,

https://doi.org/10.1007/978-3-030-67365-9_9 
cosmopolitanism as an everyday experience or an "ordinary cosmopolitanism" that "emerges from interactions in encounters between individuals" (Plage et al. 2017: 4) and "urban alchemy" (Müller 2011). I use this concept to analyze the space of Saint Lawrence Boulevard in Montréal, also called the Main in reference to Main Street.

Saint-Lawrence Boulevard is a landmarker for Montreal, cutting the isle from the south to the north in two halves, and the place where address numbers start. It manifests the gap between "two solitudes" (MacLennan 1945) - the French-speaking eastern part of the city and the English-speaking areas in the western part. It is also a bond, a passage and a melting place, where immigrants settled throughout the twentieth century. The street serves as a real backbone through several neighborhoods it runs through: Little Italy in the north, Portuguese and Jewish communities in the central sector and Chinatown in the south (see Fig. 9.1). The names of these streets and neighborhoods once symbolized poverty, marginalized communities or ghettos. And in many narratives of Montreal's social geography, "this 'immigrant' or 'ethnic corridor' was seen as a world apart, a buffer zone between the French and the English. This space, unlike the supposedly homogeneous English and French blocs, was recognized as a cosmopolitan milieu" (Germain and Rose 2000, 215). These neighborhoods are not enclaves but instead show changing boundaries in their exchanges and overlapping. Thus, there is not a strong partition between communities; instead, it is their co-presence that creates cosmopolitanism.

By the early 20th century the Main had become a cosmopolitan highway, a "third city," neither French, nor English, along which each ethnic group passed. Some rested there only briefly, others for a longer time. There was a constant ebb and flow, one group replacing another as soon as a vacuum formed. (Gubbay 1989, 57)

But these neighborhoods have been undergoing processes of both social and urban change as well as gentrification. Cosmopolitanism has spread throughout the city and is no longer reduced to the Main: migrants are now present everywhere in the city as well as in the suburbs. But still, in many scholarly or popular narratives, the boulevard is described as cosmopolitan and as a unique place in the city.

This article is based on my doctoral thesis on the geography of cosmopolitanism through narratives, practices and representations. I conducted fieldwork between 2011 and 2013 and used qualitative methodology, based on interviews, observation on the street at different times of the day (and during special events), analyses of official documentation and literature (novels and plays).

I focus on cosmopolitanism as a way to promote the urban space. Why does this image of a cosmopolitan place still define Saint-Lawrence/St-Laurent Boulevard? How is cosmopolitan branding produced and by whom? What impact does it have on representations of pedestrians and inhabitants? After showing that cosmopolitanism is used as a brand for the city of Montreal as a whole, I focus on Saint Lawrence Boulevard, which has been designated as a national heritage site for its very cosmopolitanism. Then I study different approaches of branding cosmopolitanism put into practice by commercial stakeholders in two different sections of the boulevard. Finally, I question the reactions of the inhabitants toward these branding strategies. 


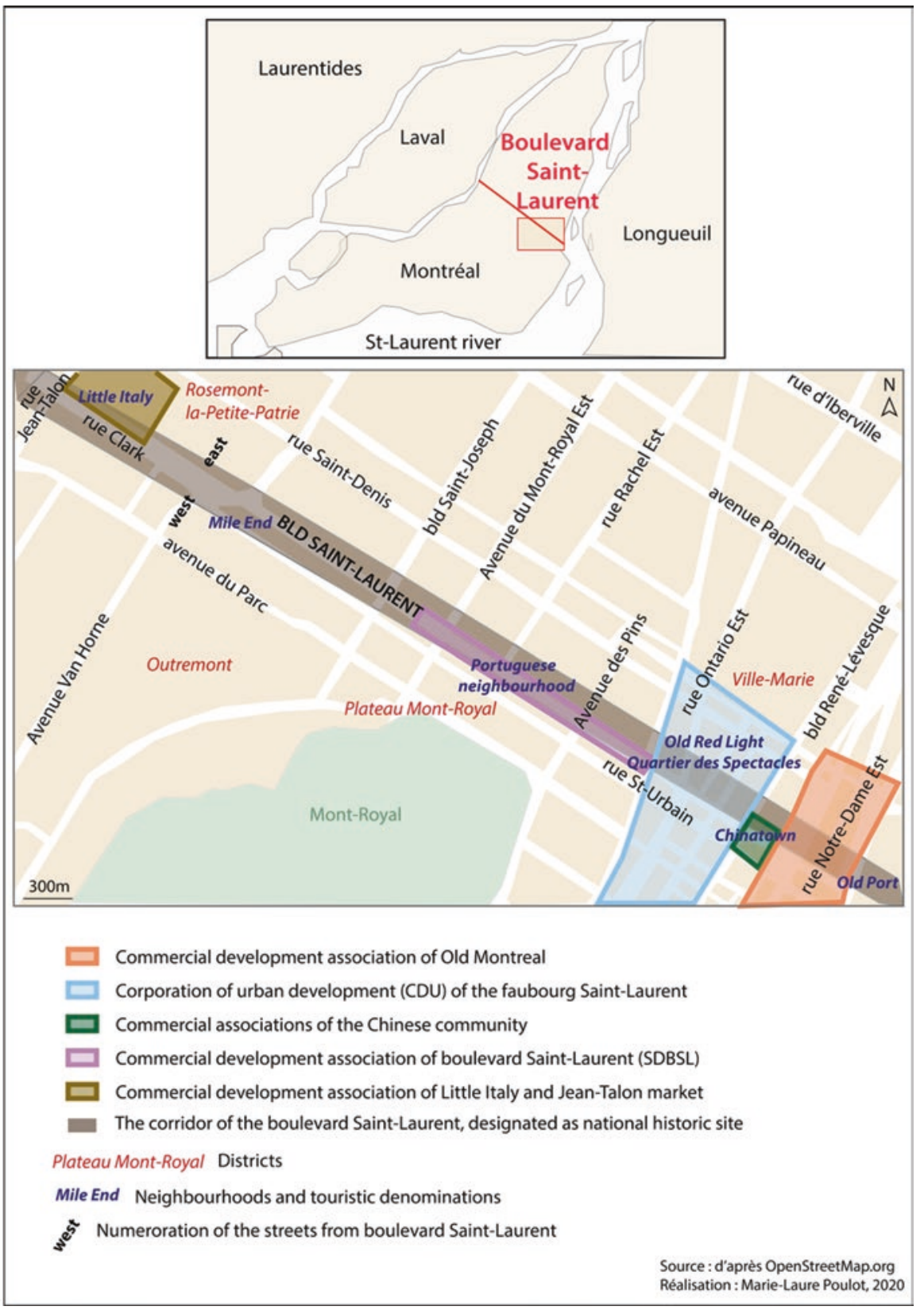

Fig. 9.1 Saint Laurent Boulevard in Montreal 


\subsection{City Branding in Montreal: Cosmopolitanism of the Saint-Laurent Boulevard}

If cosmopolitanism is often mobilized in city branding, it is especially so in Montreal, where institutional documents, tourist guides and the media all emphasize "the cosmopolitan city's vaunted bilingualism" (Bilefsky 2017) and claim that "Montreal's cosmopolitan charm [that] still seduces travelers" (Zach 2017). "Welcoming and cosmopolitan, Montréal embraces people from all over the world, who make up 20\% of the city's population" (Ville de Montréal 2017). Place branding can be defined as a

concept in policymaking that draws together a number of strategies and practices carried out primarily by local governments. The objective of place branding is to attract mobile resources to a certain place, commonly in the form of social, economic or cultural capital, in response to the apprehension of increasing competition between places. (Andersson 2015, 17)

In order to be attractive for the creative class, a city has to be cosmopolitan (Florida 2002, 227) and this idea is used by politicians and economic stakeholders, notably in branding places, where "marketing and consumption have a significant role in giving economic value to difference" (Vanolo 2017, 9).

In Montreal, the cosmopolitan urban imaginary is used for both economic and political purposes to develop and attract investors, tourists and new dwellers and to present the metropolis differently from the rest of Canada and the United States. Branding cosmopolitanism in Montreal tends to mix both the brand image destined to foreigners and the urban imaginary shaped by and for inhabitants. These discourses come from different stakeholders, such as economic agents, the advertising and tourist sector or even the City (and the districts). The Main and its "ethnic neighborhoods," which have been officially recognized by the municipality (Chinatown, Little Italy and the central section with Jewish, Portuguese and Spanish communities), are present in tourist guides for Montrealers and international tourists. The City has also baptized some of the places along the boulevard with toponyms linked to the old immigration, such as park of Portugal or Açores Park in the Portuguese sector.

In this cosmopolitan branding and recognition of the city, the boulevard is one of the most important places since it concentrates the old ethnic neighborhoods. I thus focused on the scale of the street to study cosmopolitanism (Hall 2012). The scale of the street brings together several scales: local ones - the street, the neighborhood, the block, public places and squares and shops and businesses - but also provincial and federal ones as the boulevard Saint-Laurent was designated a national heritage

\footnotetext{
${ }^{2}$ There are also political directives and documents which assert the cosmopolitan vision of the city. See, for example, Montreal Declaration for Cultural Diversity and Inclusion (2004), at http://ville. montreal.qc.ca/pls/portal/docs/PAGE/CHARTE_MTL_FR/MEDIA/DOCUMENTS/ Declaration_diversite_inclusion_2004_en.pdf
} 
site by The Historic Sites and Monuments Board of Canada in 1996 (Fulton and Vermette 1996).

\subsection{Narrating an Idealized Cosmopolitanism as Heritage}

History and also literary fiction are used by Park Canada ${ }^{3}$ to describe boulevard Saint-Laurent as a place that shows several waves of immigration. The commemorative plaques at both ends of the street (in the old port and Little Italy) describe the boulevard's heritage site status in the following terms:

Along this strong sinewy backbone of Montréal, in a kaleidoscope of neighborhoods such as Chinatown, the Jewish and Portuguese quarters, and Little Italy, a vibrant, cosmopolitan heart for the city has been forged.

Literary fiction, both English-language and French-language, has contributed to the conception of the Main as a symbolic cosmopolitan place in the urban imagination of Montreal and as a national heritage. The boulevard holds an important place in the works of renowned authors like Mordecai Richler or Michel Tremblay as well as in more recent novels and plays. These narratives - fictions but also non-fictions tend to convey the image of a small-scale neighborhood landscape with close social ties and a multiethnic history. Even though many immigrant communities left to settle elsewhere in the city, contemporary narratives plough back into old ones: it is this very period of waves of immigration which is passed on in the collective memory as one of tolerance, brotherhood and belonging. These narratives create a nostalgic image of the whole street and of some surrounding neighborhoods.

One of the neighborhoods of the boulevard, Mile End, is often described as the personification of cosmopolitanism, a "plural and hybrid social reality" (Simon 1999, 23) or "the crystallization of an emerging montrealness" (Olazabal 2006, 8). For example, the official touristic presentation of Mile End says,

Like any neighborhood with flavor, it's the cultural layers that have made Mile End what it is today. Living side by side is an engaging mix of communities: Hassidic Jewish, Greek, Italian, anglophone and others who have given it its special brand of energy and kick. Expect kosher stores and bakeries and little boys with traditional side curls zipping by on scooters. (Tourism Montreal, official site)

This sector of Mile End represents the "cosmopolitan turn" (Germain 2011) of Montreal: there are no longer just ethnic neighborhoods of Italians, East European Jews, Greeks and Portuguese as in the beginning of the twentieth century but rather multiethnic neighborhoods since the diversification of immigration in the 1970s. The neighborhood is now gentrified, but an important Hassidic community still resides in Mile End and old shops still stand. The coexistence of gentrifiers with an ethnically and socio-economically diverse body of older-established residents has

\footnotetext{
${ }^{3}$ Parks Canada is a federal agency created in 1911 with a mandate to protect representative examples of Canada's natural and cultural heritage.
} 
created a shared discourse and pride in the neighborhood's cosmopolitanism (Germain and Rose 2000). But the narrative's theme of multicultural harmony and close neighborly relations denies the near total disappearance of its minority communities (Greeks and Italians mostly). It also ignores the tensions due to the presence of several religious and immigrant communities (see Bouchard and Taylor 2008) that I've been able to observe in the neighborhood's current social segregation: mostly of class, but also of origin and of religion with the Hassidic community or tensions related to language. There is indeed a selective nostalgic image of the Mile End, described for the "sweetness of belonging." Alberto Vanolo (2017, 15-16) uses the metaphor of ghosts as "echoes of things that once were visible," reflections and reverberations of an absent past" to describe city branding strategies: "some undesired elements are transformed into ghosts, and some ghosts (such as old identities, old buildings, old stories, old stereotypes or memories) are evoked and transformed into visible presences such as images, stories, slogans, tourist sites, etc.". In the narrative of Montreal - and Saint Lawrence Boulevard - some traces of communities and places are turned into visible marks while some past stories are not shown or even erased. Elements of the past are repositioned in the present and used in city branding and place making. Beyond the political branding and heritage, the street also shows a commodified cosmopolitanism for tourist and economic purposes.

\subsection{Branding Cosmopolitanism: Commercial Stakeholders in Ethnic and Touristic Neighborhoods}

"Ethnic" and "multiethnic" neighborhoods along the boulevard clearly highlight the assets of cosmopolitanism through food, shops, associations or symbols such as colors, flags or decorations. Marks of the old immigrant presence are visible along the boulevard: immigrant groups and ethnic entrepreneurs have been building particular landscapes, "ethnoscapes" (Appadurai, 1990), from façades to shop and restaurant interiors. Public and private actors produce these neighborhoods through urban planning, marketing strategies and events (celebrations, festivals and urban tours). But how is cosmopolitanism "produced and sustained through different forms of urban governance, and in particular the production of distinct cosmopolitan quarters and sectors through policy and planning" (Binnie et al. 2006, 14)? And who is behind this construction of landscape?

On top of city officials (through public recognition and toponyms) and Park Canada (through the federal designation) who promote the boulevard as a cosmopolitan place, the other really important actors are commercial development associations (SDC), the equivalent of Business Improvement districts (BID) in the United States or Business Improvement areas (BIA) in the rest of Canada. This model of "self-imposed financing mechanisms implemented by businesses and property owners for local improvements, specifically the enhancement of public 
services" (Hoyt 2004, 367) are present in many states. In each case, shopkeepers (and landowners in BIA) decide to organize themselves in associations to develop and promote the street or the neighborhood.

From the south to the north of the boulevard, five different associations exist and organize several actions in order to promote the street and/or the neighborhood depending on their perimeter: Old Montreal, the historic district of the city, Chinatown, Quartier des Spectacles, Saint-Lawrence boulevard (SDBSL) and Little Italy (see Fig. 9.1). These branding initiatives (logos, slogans, advertising campaigns, etc.) promote a different narrative of the concerned space: a mono-ethnic one in Little Italy, a more diverse one in the central section.

\subsubsection{Little Italy: Italianity as a Brand for the Boulevard and the Neighborhood}

In the north of the boulevard, the commercial development association of Little Italy has oriented its branding toward a certain vision of Italy with arches, greenwhite-red flags, Italian connotations (Rome Antics, Café Italia, Corneli, Galleria della Sposa, etc.) for the names of shops, and decorations with the name of the neighborhood (see Fig. 9.2). ${ }^{4}$ The SDC has also appointed the Toronto advertising company OPEN to set up a new branding strategy for the neighborhood. A logo and the slogan "vivere Emozione" have been created to let Little Italy stand out from the other neighborhoods (see Fig. 9.2). The letter V is supposed to be the symbol gathering different textures that refers to the urban multilayered neighborhood and identifies the three commercial components of Little Italy: gastronomy, sport and culture. The new official guide describes Little Italy with all the Italian references and clichés:
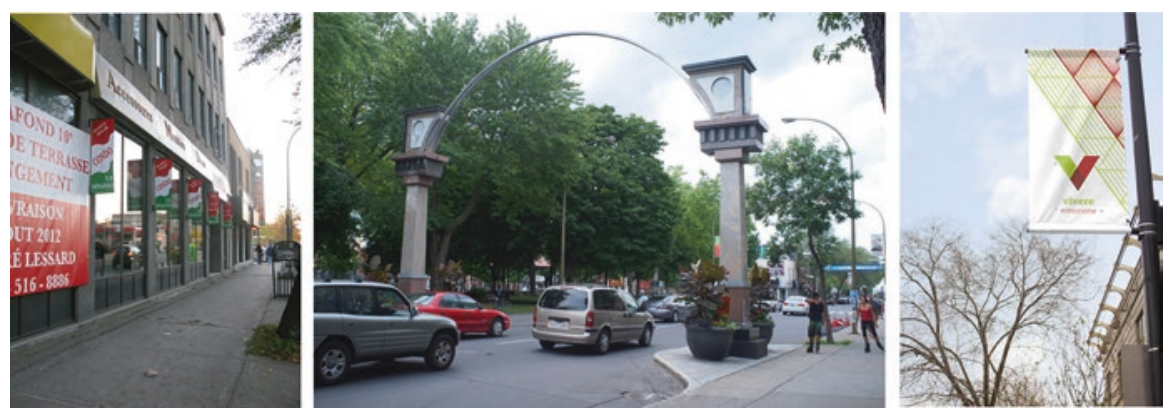

Fig. 9.2 Little Italy with colors of the Italian flag, arch on the boulevard and banner with the new slogan "Vivere Emozione." (ML Poulot, 2013, 2015)

${ }^{4}$ A first informal Association for the promotion of the Little Italy was created in the 1970s, but the SDC has officially existed since 2009, bringing together 240 merchants. 
Imagine the soft sound of bocce being played on the sand field, the lovers enjoying an outdoor movie night under a pergola and the children eating a pizza or an ice cream on the grass. This is the Dante Park.

Imagine enjoying the creamy taste of an expresso while participating in a debate on Italian soccer during Little Italy's street festivities. This is Vivere Emozione.

This new identity is the synthesis of a Little Italy that "does not imagine, but lives through the mixture of its multi-generational urban habitat" (Montréal Little Italy 2016).

This new identity is the synthesis of a Little Italy that "does not imagine, but lives through the mixture of its multi-generational urban habitat" (Montréal Little Italy 2016). The director of the OPEN Agency explains that "neighborhoods of large cities now enjoy a similar reputation to the major cities that house them. By force of circumstances, the competition and the importance of outstanding become a necessity" (Infopresse 2014).

Lastly, the branding is now specialized and professionalized. A few years ago, it was the association itself who did the branding, asking only for an advertising agency to help with the design of the logo. The marketing strategy is now externalized, performed by marketing and advertising professionals. The same phenomenon can be seen in several SDC in Montreal.

This is then a strategy that pertains to multiculturalism with one single identity put forward. Just as Little Italy's "corporate multiculturalism" "necessarily limits intercultural communication and understanding, and tries to protect community boundaries and traditional identities" (Bianchini 2004, 4), so too for Chinatown. On the contrary, in the central section of the street, different communities and origins are represented and highlighted.

\subsubsection{The Central Section of the Boulevard: Toward a More Inclusive and Cosmopolitan Image}

In the central section of the boulevard, between Sherbrooke Street and Laurier Street, the SDC of the boulevard (SDBSL) is trying to embrace several waves of immigration (from Portugal, Spain, Italy, Greece, East European Jews). ${ }^{5}$ Different marks and initiatives are visible throughout the street.

A group of Portuguese residents and an elected representative of the community have, for example, imagined a special project of marking. They did not put entrance doors, like in Little Italy or Chinatown, but instead benches on both sides of the sidewalks. These "benches of stone and words" are made of azulejos (Portuguese mosaic) and urban dwellers can read inscribed quotes from Portuguese novelists

\footnotetext{
${ }^{5}$ The association of merchants was created in 1978 as "the international village Boulevard SaintLaurent." Its perimeter has expanded and the association was officially transformed into a SDC in 2000. It now counts more than 700 businesses, organisms and companies.
} 

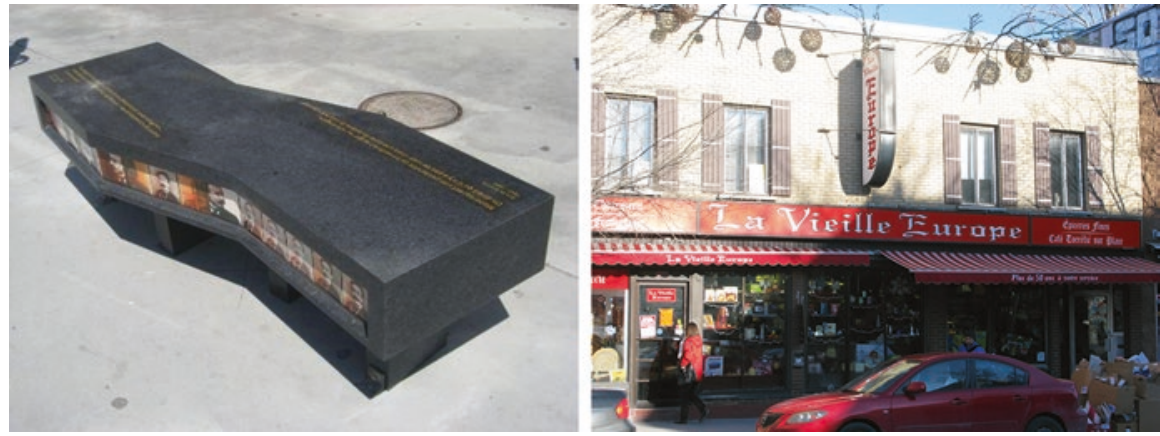

Fig. 9.3 The "benches of stone and words" and the shop "La Vieille Europe" on Saint-Laurent Boulevard (ML Poulot, 2012, 2013)

and writers (see Fig. 9.3). They are supposed to represent the Portuguese community, a bridge between Anglophone and Francophone and other communities. One of the members of the Portuguese community, who is also involved in the SDBSL, explains that they want to do something different than the Business Improvement Area in Toronto called Little Portugal that has existed since 2007:

It's been a while since we are working for the official creation of the Portuguese neighborhood. Because nowadays, everybody knows where it is. In Toronto, they created "The little Portugal." I respect that, that's what people wanted on Dundas street, with the Portuguese flag. But I find it very ghetto-like. And the Portuguese community of Montreal has never been a ghetto-community, never! (Interview, August 2013)

Other SDBSL initiatives exist, such as Dia Das Montra, which picks up a tradition from the Azores and extends it to every storefront (shop owners decorate their store windows and the best one receives a prize). The SDBSL website also underlines the importance of other communities by highlighting stores like La Vieille Europe or L'española (an old Spanish bookstore that sells lots of other Spanish and Latino goods, objects, food or drinks) [see Fig. 9.3]. It also indicates different route suggestions in order to put forward the identity and the history of the Main, linked to the old Jewish presence along the street. ${ }^{6}$

Even if the SDBSL still promotes the cosmopolitan history of the boulevard, its recent actions have been about building a more artistic and creative identity less linked to the historic waves of immigration. ${ }^{7}$ The new street art festival MURAL created in 2013, for example, tends to put Montreal on national and international map of street art by creating a successful event whose artworks do not necessarily address the cosmopolitan past of the street.

\footnotetext{
${ }^{6}$ These initiatives are linked to the Museum of Jewish Montreal (http://imjm.ca/) "that collects maps, and shares the history and experiences of the Montreal Jewish community online and through walking tours, exhibits, and other public programming."

${ }^{7}$ See this project to commemorate three businesses that have been created by the Jewish immigrants: http://boulevardsaintlaurent.com/en/nouvelle/le-main-personnage/
} 


\subsection{Representations of the Boulevard by the Inhabitants: Authenticity or Artifice?}

What public is targeted by these branding strategies and what are their representations? These branding strategies are, of course, destined for the different communities who seek public recognition. But they are also destined for different users, like tourists, dwellers, new inhabitants, investors, new shopkeepers, etc. These actions are meant to create a dynamic neighborhood, to boost economic renewal, to promote shops and businesses, and, finally, to attract tourists, both domestic and international. Visits and walking tours are organized by several associations in the different districts of the boulevard for both Montreal residents and international tourists to show off urban cosmopolitanism, the diverse food and culture available and to commemorate the heritage of the street. These visits also bring in students from all over the province of Quebec in order to celebrate traces of immigration and the different religions present in Montreal. These visits thus contain an educational purpose in challenging received ideas and prejudices, even if in these branded places, "the imagery projected to visitors may reconfirm rather than challenge stereotypes" (Shaw et al. 2004).

As for city dwellers, both reactions exist: some denounce the commodification of space, whereas others see these neighborhoods as authentic. This is particularly true for the central section of the boulevard, which most inhabitants see as an authentic space (Zukin 2010). These dwellers link authenticity to cosmopolitanism: the fact that several languages can be heard on the street, that businesses are owned by immigrants or descendants of immigrants, that the goods sold are specific to one country or one region other than Quebec or Canada. As one of the shopkeepers says, "the boulevard has always had its own identity, which is still the same today: a historic street, a nonconformist one and an authentic one" (interview, May 2013). But in my interviews with city-dwellers and users, there is a paradoxical way of seeing those spaces: authenticity is sought but some inhabitants regret that Chinatown or Little Italy are artificial neighborhoods created for tourists, resuming the traditional debate between "superficial" and "authentic" cosmopolitanism (Molz 2011). One resident who had lived in the Portuguese neighborhood in the 1980s says that "it's a shame to line up some districts toward tourism, it's artificial" (interview, December 2011). Another dweller even talks about fake recreation:

\footnotetext{
In fact, it's a bit propaganda for the boulevard: they try to make a myth of it. I used to stroll on the boulevard with my children, to show them the turmoil of the street. It wasn't a rich street, it was a street of ethnic and mom and pop shops that served a local population. But now, it's not anymore [...] It's a memory. [...] In fact, we are in a generalised marketing and communication strategy nowadays. You don't get the experience they're selling, you don't get what the federal designation [the national heritage site] is telling. (Interview, May 2013)
}

Residents from immigrant backgrounds and their descendants no longer live on the street or are a minority if they do. The old shops held by those immigrants are supposed to embody cosmopolitanism by representing the remains of the cosmopolitan past of the street. The commercial development associations are therefore the 
guardians of this cosmopolitan image and carry on its representation and recreate it, as one of the residents explains:

The people who have nostalgia for the most part didn't live it [the boulevard]. Yeah, sure we have nostalgia, but we didn't live here, it's romanticized. [...] And the young people who are trying to recreate something, they are trying to reinvent something. (Interview, May 2013)

But cosmopolitanism put forward on the boulevard is described by some inhabitants as a merchandise built by the branding strategies of the municipality and the commercial development associations in order to attract investors and new dwellers.

\subsection{Conclusion}

In conclusion, it is clear that branding "is both a generalised label to describe emergent social and economic spatial formations and a narrative trope that makes one part of the city analytically visible" (Keith 2005, 117). Branding selects neighborhoods and places that are potentially interesting in attracting people and capital but at the expense of other places and neighborhoods which may be cosmopolitan but are not branded as such. The narratives around Saint Lawrence Boulevard return back to old ones; several buildings have changed their earlier function and shops have adapted their commercial offer to new residents. This consumerism of difference tends to a commodification of otherness and is often reduced to the "easy faces of cosmopolitanism." These branding initiatives are received in different ways by inhabitants; some only see them as "consumerist cosmopolitanism" (Calhoun 2002) while others link them to the daily experiences of the hustle and bustle of cultural communities. The boulevard thus constitutes a useful space to understanding narratives on this historic cosmopolitanism, the actions of different public and private stakeholders and its consequences on space and representational orders for dwellers. Nowadays, cosmopolitanism is more and more covered up by a creative and cultural identity, notably in Mile End and the central section of the boulevard, while Chinatown and Little Italy are sticking to their single ethnic branding in a tourist strategy similar to one found in other North American cities such as New York, Toronto or Boston. Processes of gentrification, new art galleries, businesses, festivals and activities are "branding neighborhoods in terms of distinctive cultural identities" (Zukin 2010, 3) with a hint of cosmopolitanism in order to shape an authentic identity responsive to the demands of social preservationists (Brown-Saracino 2009) as proximity and as a community experience. 


\section{References}

Andersson, I. (2015). Geographies of place branding: Researching through small and mediumsized cities. Meddelande fran Kulturgeografiska institutionen, 148, Stockholm University.

Appadurai, A. (1990). Disjuncture and difference in the global cultural economy. Theory, Culture \& Society, 7, 295-310.

Bianchini, F. (2004, February 7-10). A crisis in urban creativity? Reflections on the cultural impacts of globalisation, and on the potential of urban cultural policies. Paper presented at the international symposium The Age of the city: The Challenges for Creatives Cities, Osaka.

Bilefsky, D. (2017, December 5). Quebec Tries to Say Au Revoir to 'Hi,' and Hello to 'Bonjour'. New York Times. At https://www.nytimes.com/2017/12/05/world/canada/bonjour-hiquebec.html

Binnie, J., Holloway, J., Millington, S., \& Young, C. (2006). Cosmopolitan Urbanism. London: Routledge.

Bouchard, G., \& Taylor, C. (2008). Building the future: A time for reconciliation. Report of the Commission de consultation sur les pratiques d'accommodement reliées aux différences culturelles. Québec: Gouvernement du Québec. At https://www.mce.gouv.qc.ca/publications/ CCPARDC/rapport-final-integral-en.pdf

Brown-Saracino, J. (2009). A neighborhood that never changes: Gentrification, social preservation, and the search for authenticity. Chicago: University of Chicago Press.

Calhoun, C. (2002). The class consciousness of frequent travellers: Towards a critique of actually existing cosmopolitanism. In S. Vertovec \& R. Cohen (Eds.), Conceiving cosmopolitanism: Theory, context and practice (pp. 86-109). Oxford: Oxford University Press.

Florida, R. (2002). The rise of the creative class: And how It's transforming work, leisure, community and everyday life. New York: Basic Books.

Fulton, G., \& Vermette, L. (1996). Rapport de la Commission des lieux et monuments historiques du Canada, L'arrondissement historique du Boulevard Saint-Laurent (La Main). Direction des services historiques, Parcs Canada.

Germain, A. (2011). The fragmented or cosmopolitan Metropolis? A neighbourhood story of immigration in Montréal. Publication CMQ-IM 44, Metropolis.

Germain, A., \& Rose, D. (2000). Montréal: The quest for a Metropolis. Chichester: Wiley.

Gubbay, A. (1989). A street called the main - The story of Montreal's Boulevard Saint Laurent. Montreal: Meridian Press.

Hall, S. (2012). City, street and citizen: The measure of the ordinary. London: Routledge.

Hemelryk, D. S., Kofman, E., \& Kevin, C. (Eds.). (2009). Branding cities: Cosmopolitanism, parochialism, and social change. New York: Routledge.

Hollinger, D. A. (1995). Postethnic America: Beyond multiculturalism. New York: Basic Books.

Hoyt, L. (2004). Collecting private funds for safer public spaces: An empirical examination of the business improvement district concept. Environment and Planning B: Planning and Design, 31(3), 367-380. https://doi.org/10.1068/b29124

Infopresse: la Référence des professionnels des communications et du design. (2014, May 14). La Petite Italie se refait une beauté. At http://www.infopresse.com/article/2014/5/14/ la-petite-italie-se-dote-d-une-nouvelle-image-de-marque

Kavaratzis, M., \& Ashworth, G. J. (2005). City branding: An effective assertion of identity or a transitory marketing trick? Tijdschrift voor Economische en Sociale Geografie, 96(5), 506-514.

Keith, M. (2005). After the cosmopolitan? Multicultural cities and the future of racism. New York: Routledge.

Kymlicka, W. (1998). Finding our way: Rethinking ethnocultural relations in Canada. Oxford: Oxford University Press.

Létourneau, J. (2003). Reposer la question du Québec. Options politiques, 24(10), 44-49.

MacLennan, H. (1945). Two solitudes. Toronto: Collins.

Molz, J. G. (2011). Cosmopolitanism and consumption. In M. Rovisco \& M. Nowicka (Eds.), The Ashgate research companion to cosmopolitanism (pp. 33-52). London: Routledge. 
Montréal Little Italy. (2016). Official guide.

Müller, F. A. (2011). Urban Alchemy: Performing urban cosmopolitanism in London and Amsterdam. Urban Studies, 48(16), 3415-3431.

Olazabal, I. (2006). Le Mile-End comme synthèse d'une montréalité en devenir. Les Cahiers $d u$ Gres, 6(2), 7-16. https://doi.org/10.7202/014444ar

Plage, S. I. W., Woodward, I., \& Skrbis, Z. (2017). Cosmopolitan encounters: Reflexive engagements and the ethics of sharing. Ethnic and Racial Studies, 40(1), 4-23.

Shaw, S., Bagwell, S., \& Karmowska, J. (2004). Ethnoscapes as spectacle: Reimaging multicultural districts as new destinations for leisure and tourism consumption. Urban Studies, 41(10), 1983-2000.

Simon, S. (1999). Hybridité culturelle. Montréal: l'île de la tortue.

Söderström, O. (2006). Studying cosmopolitan landscapes. Progress in Human Geography, 30(5), 553-558.

Tourism Montreal. Official site. At http://tmuatweb.tourisme-montreal.org/Press/Press-kit/ Neighbourhoods/mile-end-montreal

Vanolo, A. (2017). City branding: The ghostly politics of representation in globalising cities. London: Routledge.

Ville de Montréal. (2017). Montréal, métropole culturelle, At a glance 2016. At http:// ville.montreal.qc.ca/pls/portal/docs/PAGE/PA0717_FR/ COUP_DOEIL_2016_EN.PDF

Zach,E.. (2017, April 13). At 375 Montreal's cosmopolitan charm still seduces travelers. Washington Post. At https://www.washingtonpost.com/lifestyle/travel/at-375-montreals-cosmopolitancharm-still-seduces-travelers/2017/04/13/15d0e178-155d-11e7-833c-503e1f6394c9_story. html?utm_term $=.7 \mathrm{e} 3 \mathrm{~b} 3658597 \mathrm{a}$

Zukin, S. (2010). Naked city: The death and life of authentic urban places. New York: Oxford University Press.

Open Access This chapter is licensed under the terms of the Creative Commons Attribution 4.0 International License (http://creativecommons.org/licenses/by/4.0/), which permits use, sharing, adaptation, distribution and reproduction in any medium or format, as long as you give appropriate credit to the original author(s) and the source, provide a link to the Creative Commons license and indicate if changes were made.

The images or other third party material in this chapter are included in the chapter's Creative Commons license, unless indicated otherwise in a credit line to the material. If material is not included in the chapter's Creative Commons license and your intended use is not permitted by statutory regulation or exceeds the permitted use, you will need to obtain permission directly from the copyright holder. 